\title{
The Impact Of Sarbanes-Oxley Act
}

Yousef Jahmani, Savannah State University, USA

William A. Dowling, Savannah State University, USA

\begin{abstract}
The Sarbanes-Oxley Act (SOX) was signed into law in July 2002, with the express purpose of restoring public confidence in corporate financial statements. Prior to the enactment of Sox, investors suffered significant losses due to corporate failures brought on by financial malfeasance.
\end{abstract}

\section{THE SARBANES-OXLEY ACT: FIVE YEARS LATER}

\section{INTRODUCTION}

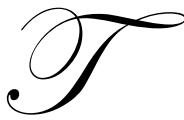

he Sarbanes-Oxley Act (SOX) was signed into law in July 2002, with the express purpose of restoring public confidence in corporate financial statements. Prior to the enactment of Sox, investors suffered significant losses due to corporate failures brought on by financial malfeasance. Specifically, SOX was intended to address issues of accounting fraud by attempting to improve both the accuracy of and reliability of corporate disclosures. It also increased the accountability of company executives and members of the board of directors. The act was a direct consequence of the public disgust with a series of financial scandals that lead to collapse of large firms as best exemplified by Enron and WorldCom. However, Enron and WorldCom are by no means the only ones, but just the most infamous. These failed companies had engaged in massive accounting frauds to the extent that they undermined the antifraud and mandatory disclosure provisions of federal securities laws. To put the issue in perspective, the S\&L debacle of the 1980s cost investors and taxpayers less than $\$ 5$ billion. As a direct result of the 30 largest accounting fraud cases from 1997 to 2004, investors lost an estimated $\$ 900$ billion. (The Economist 2005)

A distinguishing factor of this incident was the blame directed towards the accounting profession; auditors specifically were blamed for having compromised their independence. The record revealed that the revenues that auditors generated from consulting services from the firms they were auditing exceeded those generated from conducting the audit. This immediately raised the question regarding the loss of independence on the part of the auditors.

In this chaotic environment, SOX was spawned. It was conceived in controversy and has remained contentious. Proponents of SOX believe that it was necessary to restore public faith in published financial statements by assuring that accounting records were accurate and could be relied upon. For this group Sox was absolutely necessary to prevent another outbreak of financial scandals such as those of the Enron and WorldCom era. There was a growing perception among the investing public that most of the scandals could have been prevented had there been a governmental agency responsible for monitoring and preventing such accounting irregularities.

The opinion with respect to Sox has been, as expected, symmetric. Opponents argued that Sox would be detrimental to the economy; that the burden would fall too heavily on smaller public firms; that the costs of implementing Sox with all its requirements would far exceed the benefits gained. The fact that there was a spike in the number of public companies that were privately sold, that relocated outside the US and relisted themselves on foreign exchanges lends some credence to the opposing view. Lending further support to the opposing view was the increasing number of foreign and domestic companies who cancelled plans for listing on U. S. exchanges.

Recognizing the concerns with respect to Sox, there has been some easing of the requirements and their implementation by the body charged with implementation of the act. Given the significance of the claims involved, debate has continued and will continued for years to come. Given the preceding, the purpose of this paper is to 
synthesize the literature on the benefits and the costs of Sox. To accomplish this, the remainder of the paper will be segmented into four parts: part one, a summary of Sox and its requirements, parts two and three will explore the benefits and costs respectively, and part four containing our conclusions and observations will end the paper.

\section{Part 1 - The Sarbanes-Oxley Act of 2002}

SOX is easily the most significant piece of financial legislation since the initial legislation regulating the securities markets in the 1930s. It has had a profound effect and has dramatically changed the accounting industry, financial reporting, and the auditing of public companies in particular. Most would argue that the changes have been positive, even so, the changes have come at great cost.

The most significant changes brought about by the act include the following.

(1) SOX represented the initial foray of governmental oversight into the accounting industry. A quasigovernmental organization called Public Company Accounting Oversight Board (PCAOB) was created and charged with direct oversight and regulation of the accounting industry. PCAOB works in tandem with the Securities and Exchange Commission (SEC) to oversee all public accounting firms and public companies with the expressed purpose of protecting " the interests of investors and further the public interest in the preparation of informative, fair and independent audit report" (PCAOB 2002). PCAOB operates under the same jurisdiction as the SEC and PCAOB. It has the legislated authority to discipline any violators of Sox. Further, the enabling legislation for PCAOB empowered it to issue standards on its own volition or it may adopt standards issued by other groups or organizations for the purposes of regulating auditing, related attestation quality control, setting ethical guidelines, assuring auditing independence and taking disciplinary actions and procedures when its mandates are not met.

(2) SOX contains several sections that directly impact (limit) the interaction and scope of services auditing firms are able to perform for public companies. For example, Section 201 restricts the scope of services auditing firms can provide. Traditional bookkeeping services, accounting information system design and implementation, actuarial services as well as most forms of managerial consulting not directly related to audits are prohibited for firms who are contracted to provide audit services. (The only exception was for the provision of tax services.) Further, the audit committee of the Board of Directors of the employing firm must pre-approve all audit and non-audit services provided by its auditors. To reduce potential conflicts of interest, Section 203 requires auditing firms to rotate the managing partner off a client's audit at least every five years when engaged in a long-term relationship. Further, Section 204 mandates that the accounting firm reports directly to the company's independent audit committee (typically a sub-committee of the Board of Directors).

(3) Section 302, included several requirements related to the management of public companies. Both the chief executive officer (CEO) and the chief financial officer (CFO) are now required to take personal responsibility by personally certifying both the quarterly and the annual financial statements and disclosures.

(4) Section 401 requires that all material off-balance sheet transactions and relationships with unconsolidated entities, which can or will have economic effects on the company, must be disclosed in the quarterly and annual reports. In addition, Section 403 requires that any transaction involving management or principal stockholders needs to now be disclosed by the second business day of the transaction.

(5) Easily the most contentious part of Sox is Section 404, wherein management is required to issue a statement in each annual report issued by the company on its responsibility for and its current assessment of (a) the company's internal control structure and (b) the effectiveness of those controls. This section also requires the auditor to attest to, and make an assessment of management's report on the company's internal control effectiveness for financial reporting.

Although SOX has been in effect for only five years, there has been a visceral reaction by the business community to Section 404 . While the majority of corporate executives indicate that the section has been instrumental in improving their internal control standards, there is opposition to certain aspects of Section 
404 and as a result, there is a significant movement to revise certain aspects of this section (Sweeney, 2005).

(6) SOX, Section 409 served to greatly reduce the reporting disclosure timetables on information pertaining to material changes in the company's operations and financial conditions. Additionally, SOX requires public disclosure of information that was not previously required with the expressed purpose of improving the accuracy of and the completeness of the disclosure of financial information.

(7) Congress included not only those accounting firms and companies whose stocks trade publicly, but also all registered foreign companies and all non-public companies whose debt securities are publicly traded, whose equity or debt securities are registered under the Securities Exchange Act, who are required to file reports under that Act, or who have filed a statement for a public offering under that Act as being subject to the provision of SOX.

Admittedly, those points above cover only a small portion of SOX but these are the sections, especially Section 404, which have generated the most controversy. They are clearly most debated and studied sections and ramifications with regards to costs and benefits. The results of the analysis of the cost-benefit tradeoff for SOX are clouded at best. Many have argued persuasively that while benefits of Sox are good for investors and companies as a whole, the costs of the benefits far exceed their worth.

\section{Part 2 - The Sarbanes-Oxley Act of 2002 - Direct and Indirect Costs}

The legislative intent behind SOX was to require that all public firms be covered by its provisions. As enacted, SOX has increased the services that companies will require to comply with the provisions of SOX. The precise magnitude of the costs of these services is still unknown. However, one can address the costs by bifurcating them into the categories of direct costs and indirect costs. Intuitively, direct costs are measurable, while indirect costs are often times difficult to quantify and measure.

\section{Direct Costs}

Since SOX was enacted, the business community has, in very strident terms, repeatedly expressed concerns for the costs incurred to comply with its requirements. Initially, the SEC posited an estimate that the additional workload required to comply with SOX would be five hunderd additional man hours. Not surprisingly, the SEC has received numerous complaints that its estimate was so unreasonable as to be laughable. Responding to criticism, the SEC revised its estimates, in June of 2003. The new estimate to comply with SOX was an additional 383 man hours with an estimated dollar value of $\$ 91,000$ (excluding the auditing fees per company per year). Experience has shown that even this estimate is unrealistically low.

Several academic researchers have examined the cost of compliance. Zhang (2007) tested the market reaction to events leading to the passage of SOX. He found that the cumulative abnormal return was significantly negative suggesting that the market regards SOX as a net drag on the valuation of the firm. Zhang showed that the cumulative loss in market value amounted to $\$ 1.4$ billion (one can easily speculate that this total includes direct compliance costs, indirect costs and the expected costs of future compliance). The results of this Zang's study suggest that Section 404 of SOX, where in an annual control test is required, imposes significant real costs on public companies. Zang's study is limited by the lack of control group of comparable firms unaffected by SOX to isolate some confounding variables extant at that time (the new requirements issued by NASDAC and the economic conditions at that time). (Leuz 2007).

Asthana, Balsam, and Kim (2004) find that the ratio of audit fees to assets increased between 2000 and 2002. They noted that there was a positive relationship between size, risk and audit fees. Further, they determined that on average all the clients of the "Big Four" audit firms experienced a large increase in absolute audit fees. They attributed the latter result to a decrease in competition in the supply of auditing expertise for multinational firms.

In 2005, Eldirdge and Kealey examined the costs of the internal control audit for a sample of Fortune 1000 companies. They found that for 2003 -2004 alone, average audit fees increased \$2.3 million. 
During the last five years, there have been several other surveys that have attempted to measure the costs of compliance of companies covered by SOX. In 2005, a study by the Financial Executives International (2005) attempted to determine the cost of complying with Section 404. For large cap companies (those with market capitalization above $\$ 750$ million) the FEI found that the cost of compliance with this section averaged $\$ 4.3$ million. A similar study for small cap companies found that an average cost of $\$ 1$ million (Economist 2006). An estimate of the cumulative compliance costs for all publicly listed companies amounted to approximately $\$ 7$ billion or $1 \%$ of their revenue (Koehn \& Del Vecchio, 2004).

Findings from other researchers support the contention of increasing costs of compliance. For example, Hartman (2007) found that total fees paid to auditors for the 2001 - 2006 period increased an average of 189\% for companies comprising the S\&P 500, 251\% for the S\&P Mid-Cap companies, and an astounding $311 \%$ for those in the S\&P Small-Cap category. These results clearly indicate the disproportional nature of compliance costs based solely on incurred auditing fees. Additionally, Hartman established that fees had increased at double-digit rates through 2004 before settling to single digit increases in 2005 and 2006. It is appropriate to point out that the fees referred to above are those paid for auditing services. In addition to auditing fees, Hartman found that the cost of legal services associated with SOX (compliance monitoring and other compliance related issues) nearly doubled between the years 2002 and 2003.

Audit Analytics conducted a study for "Compliance Week" and found that between 2003 and 2005 total auditor fees for companies required to comply with Sox increased by $66 \%$. Interestingly, Audit Analytics found that for companies not required to comply with SOX audit fees increases of $42 \%$. It has been suggested that some of the audit fee increases was due to the fact that the number of suppliers of auditing services diminished after 2002 resulting in a less competitive market for auditing services.

\section{Indirect Costs:}

Despite the "goodness" of the intentions serving as motivators for the enactment of and passage of SOX, clearly the costs were either under estimated, unforeseen or ignored. The direct costs were millions of dollars higher than original estimates, while the non-cash expenses (opportunity costs, lost investment opportunities and excessive staff burdens) were not considered. These indirect costs (non-cash expenses) are at times difficult to measure and quantify. Engel, Hayers, and Wang in 2006 released a study in which they investigated the decision of a firm to go private (go dark). They found that the number of firms going private modestly increased after the passage of SOX. Further, they found a significant positive relationship between the CAR (cumulative abnormal return) and firm size as a result of SOX.

Lost investor opportunities are directly attributable to SOX. Evidence of this can be found in the decisions of large non-domestic publicly held companies who have recently withdrawn from being listed on US exchanges or alternatively, several have announced decisions not to list on the US exchange specifically citing the compliance costs associated with SOX as the main reason. Many of these companies are choosing to list on the London Stock Exchange, which has fewer such regulations and the costs associated with being listed are lower than those required to be listed on the US exchange. Of particular significance has been the decision of several domestic firms to launch their IPO on foreign exchanges in lieu of raising capital in the US markets.

In addition to the trend to raise capital in foreign markets many domestic companies are also deciding to "go dark" rather than sustaining the costs associated with compliance with SOX. Carney (2007) found that more than $38 \%$ of the Schedule 13E-l filings for going private transactions cited the costs of compliance as the primary motivating factor in decision to "go dark". It should go without saying that there are still plenty of opportunities for investors in domestic markets. Clearly, the decision of sizable companies to exit US markets and exchanges does have a limiting effect on investing opportunities.

There are indirect costs as a result of Sox other than those associated with listing. Companies suffered significant opportunity costs during the first few years following the enactment of SOX as they focused on compliance. An August 2003 survey by CFO Magazine found 33\% of those surveyed had canceled or delayed 
strategic projects due to SOX. According to the results of the survey, executives expected that they would have to devote as much as $10 \%$ percent of their time in complying with the certifications and internal control assessment reporting required by SOX. With executives (especially middle and lower management levels) focusing so extensively on SOX compliance, it should be obvious that there would be less time for other activities - even strategic decisions.

Another significant indirect cost attributable to SOX has been the additional burden placed on finance departments when they are trying to balance the priorities of day-to-day operations and the time required for the increased documentations and reporting requirements. The stress and anxiety induced in and among employees of such departments is not easily quantified. Some have argued that such effects have been even more prevalent in accounting departments. Nevertheless, some companies are starting to realize that the additional effort required by SOX compliance demands that additional hires be made in those departments most affected by SOX compliance. In the previously cited FEI survey (2005), the authors found that with respect to complying with Section 404, most respondents felt a risk-based audit approach, reduced documentation, and flexible control problem remediation were the ways to lessen the compliance burden.

\section{Part Three - The Benefits of the Sarbanes-Oxley Act of 2002}

While the direct costs associated with the implementation of and compliance with SOX can be quantified and we can at least enumerate some of the indirect costs of compliance, when the discussion turns to benefits it quickly becomes apparent that the benefits are more subjective in nature and are much more difficult to measure and quantify. The initial problem involves capturing and quantifying all of the benefits. Numerous empirical studies and surveys have indicated that SOX has improved the reliability of financial reporting, effectiveness of corporate governance, corporate and investor liquidity and has resulted in a reduction of financial statement fraud.

(1) Reliability of Financial Information:

The original purpose behind the effort that produced SOX was to restore public confidence in the financial statements prepared by public companies. One of the main of objectives of the internal control must be to produce reliable financial information as the more effective internal controls are, the more reliable the information produced will be. As one of SOX's requirements is the maintenance of effective internal controls one should reasonably expect that reliable information would be produced. Support for this expectation can be found in several studies.

Hammersly and et al. (2005) examined changes in price and trading volume to SOX disclosures of material internal control weaknesses. Their results indicated that on the day of the disclosure of a material internal control weakness, returns were significantly negative for disclosing firms. Clearly, the market expects appropriate controls and punishes those firms where controls are found to be deficient.

DeFranco et al. (2005) found that the market reacted negatively to corporate reports of internal control deficiencies, suggesting, "Investors did not previously have the information and they deemed it economically significant".

Further support for the worth of SOX can be found in Chang et al. (2006). In this study the researchers determined that the "bid-asked" spread decreased after 302 certifications by CEOs and CFOs. This was interpreted as a market affirmation of the worth of such certifications on the reliability of the information.

Li, Pincus, and Rego in 2004 and Jain and Rezaee in 2006 found that SOX was a significant contributing factor in restoring public confidence and trust in the integrity of capital markets and marker participants' willingness to execute trades based on the company's published financial information. 
(2) Strengthening Corporate Governance:

Organizations possessing strong corporate governance provide discipline for employees and a tacit structure for the company as a whole. The presence of ethical values and of a business culture of "honesty" results in better bottom line performance. Prentice and Spence (2007) show significant positive correlation between corporate governance and financial performance.

Governance Metrics International (2005) found in a study of 2500 international companies that SOX led to a $10 \%$ improvement in corporate governance performance of U.S. companies versus their foreign counterparts.

Shadab (2007) demonstrated that corporate governance structures have a powerful positive impact on innovation by public corporations. SOX places more emphasis on financial reporting and control. It increases the independence of and size of the board of directors. SOX increases both director and manager turnover and heightens the companies' focus on regulatory compliance at all levels.

\section{Reduction of Financial Statement Fraud:}

Again, a major impetus behind the Sarbanes-Oxley Act was deliberate financial statement fraud. When committed on a large scale (as was the case with Enron and WorldCom), billions of dollars can be lost and investor confidence in financial market will be reduced. Since SOX was enacted, there has not been a major domestic corporate financial scandal uncovered other than the options back-dating scandal that occurred before July 2002 (Prentice, 2007). Further, evidence suggests that the incidence of fraud has declined relative to the pre-SOX era (Cornerstone Research 2007). Finally, with respect to this topic, in a review of SEC enforcement releases, Deloitte (2007) reported a decline in fraud incidences. This can only be interpreted as suggesting that SOX has had a positive impact.

(4) Model for private and nonprofit companies:

SOX's requirements have attracted many private and nonprofit companies to implement its provisions as best practice. This is the case even though SOX was never intended for non-public and nonforprofit companies. In a survey of the fastest-growing private US companies conducted by PriceWaterhouseCoopers' (2005), thirty percent (30\%) of the companies surveyed indicated that they were impacted or would be impacted in the near future by SOX. The most significant outcomes associated with SOX compliance was perceived by the private companies to be (1) improving documentation and testing, (2) strengthening of governance procedures, (3) strengthening of ethics and conduct codes, (4) the adopting of the "best practices" by public companies, and (5) the updating or addition of "whistleblower" policies. Most private companies see these SOX initiatives as ex ante preventative maintenance rather than ex post problem solving. Motivation was ranked as the second reason behind the adoption of SOX following the adoption as "a best business practice". Apparently, like their public counterparts, private companies are adopting SOX provisions in the quest to gain value through operational and control efficiencies.

Improving liquidity:

Several empirical studies have shown that implementation of SOX's requirements were associated with a significant improvement in market liquidity. Specifically, Bushee and leuz (2005) found that enhanced mandatory disclosure improved market liquidity by reducing information asymmetry. Eleswarapu, Thomson, and Venkatarman (2004) found that an improvement in market liquidity was accomplished through a reduction of adverse selection component of trading costs and as a consequence there was a reduction in information asymmetry. Jain, Kim and Rezaee (2006) found that liquidity measures improved following the enactment of SOX. Further, the observed improvement in liquidity measures were more pronounced for companies the nearer to compliance they were. 


\section{Part 4 - Concluding Observations}

Clearly, compliance with SOX imposes significant costs it can create sizable incremental workloads, a heighted volume of paperwork, large cash outlays, and the establishment of a new governmental bureaucracy. Despite this, companies are reporting that by going through the costly implementation process of SOX compliance corporate learning occurs and opportunities for cost reductions are available. The ongoing costs of compliance, while still significant, are actually declining as employees are becoming more knowledgeable of the requirements of SOX's provisions. Additionally, companies are finding ways in which to lessen the indirect costs of compliance (the additional non-compensated burden put on employees) by improving business processes through simplification and automation.

In spite of the "good news" associated with the implementation of SOX, the complaints remain. Thus the question must be asked, "If the benefits of SOX really outweigh the costs, why are there still many complaints and why is the US Congress continually deferring the compliance date for some companies and specifically small public companies?" Many researchers and critics have concluded that SOX, particularly Section 404, is too rigid and the cost of implementation exceed the benefits provided. There seems to be unanimity of agreement between and among the SEC, PCAOB, Congress, and most public companies that the costs of SOX compliance are excessive.

Alex Pollock suggests in his article "Send Sarbanes-Oxley to the Court of Investors," The American, May 4, 2007, that the theory most argued for making SOX, specifically Section 404, mandatory, because it protects investors, making them willing to pay more for securities, is actually a better argument for making it voluntary. According to Pollock, only by making SOX voluntary can the ultimate test of SOX be had. Are investors willing to pay a premium for companies complying with SOX? If they are, then this would be reflected in price differentials between firms who choose to comply with SOX and those who do not. If the differential is positive, SOX adds value and clearly the costs are outweighed by the benefits.

In 2007, Congress turned its attention to the issues surrounding SOX. Congress has called on the SEC to reduce the direct compliance costs for small companies regarding Section 404. Several legislators have proposed amending SOX. Most proposals are focused on Section 404. One proposal has adopted the Pollock suggestion making section 404 voluntary for smaller businesses. Others have suggested that Section 404 be voluntary for all firms.

Congress has directed the SEC to reevaluate and quantify in specific hard dollars the costs to companies complying with SOX. Responding to the flood of complaints and perhaps attempting to preempt congressional action, PCAOB issued Accounting Standard No. 5 (AS5), which amended the AS2 approach to SOX Section 404 to a more risk-related audit approach, where internal controls immaterial to financial statement reporting need not be as tediously tested.

The call for change will continue. If the US is to compete globally, corporate entities cannot afford arbitrary cost increasing actions. Concurrently, corporate officers and accounting professionals must keep in mind that SOX was self-inflicted and was a direct consequence of corporate financial malfeasance aided and abetted by some in the accounting industry. The recognition of materiality is an excellent point for future discussions of the potential cost reductions for public companies falling under the regulation of SOX. Will this be enough, probably not but at least it is a start in the proper direction.

\section{AUTHOR INFORMATION}

Yousef Jahmani is an Associate Professor of Accounting in the College of Business Administration at Savannah State University, where he teaches undergraduate and graduate courses in financial and managerial accounting. Dr. Jahmani's awards include designation as the Researcher of the Year at Albany State University and The Best Paper Award from the International Academy of Business. Dr. Jahmani's research interest is in accounting standards. 
William A. Dowling is a Professor of Finance and the Director of Graduate Programs in the College of Business Administration at Savannah State University. Dr. Dowling teaches in both the graduate and undergraduate programs. Dowling's research interests include personal finance issues, accounting standards, teaching pedagogy and intellectual capital.

\section{REFERENCES}

1. Asthana, Sharad, Steven Balsam, and Sungsoo Kim (2004). The effect of Enron, Anderson, and SarbanesOxley on the market for audit service, Working Paper, Temple University.

2. Bushee, B. J., and C. Leuz. 2005. Economic consequences of SEC disclosure regulation: Evidence from the OTC bulletin board. Forthcoming, Journal of Accounting and Economics 39(2).

3. Carney, William, (2007). "The irony of going private", Emory Law Journal, Vol. 55. No. 1, pp 141-160.

4. Compliance Week, 2007 "A Comparison of Audit Fee Changes Experienced by SOX Section 404 Filers and Non-Filers. Available at: http://www.auditanalytics.com/doc/report-af-20070223.pdf

5. Cornerstone Research, (2007): Securities class action case filings: 2007 Med-year assessment. Available at www.cornerstone.com securities.cornerstone.com.

6. Economist, (2005), Special report: A Price Worth Paying? Auditing Sarbanes-Oxley, Sarbanes-Oxley, May 21:82.

7. $\quad$ Economist, (2006), The Trial of Sarbanes-Oxley: Regulating the Business, 69 (April 22).

8. Eldridge, Susan W and Kealey, Burch T., "SOX Costs: Auditor Attestation under Section 404" (June 13, 2005). Available at SSRN: http://ssrn.com/abstract=743285 .

9. Eleswarapu, V. R., R. Thompson, and K. Venkataraman. 2004. The impact of Regulation Fair Disclosure: Trading costs and information asymmetry. Journal of Financial and Quantitative Analysis 39(2): 209-225.

10. Engel, Ellen, Rachel M. Hayes, and Xue Wang (2006) The Sarbanes-Oxley Act and firms' going private decision", Journal of Accounting and Economics.

11. Financial Executive International, (FEI) 2004. Section 404 Cost survey.

12. Financial Executive International, (FEI) 2006. Section 404 Cost survey.

13. Gus De Franco et al., (April 2005),. The Wealth Change and Redistribution Effects of Sarbanes-Oxley Internal Control Disclosures, 6 available at http://ssrn.com/abstract=706701.

14. Hammersley, Jacqueline S., Market Reactions to the Disclosure of Internal Control Weaknesses and to the Characteristics of those Weaknesses under Section 302 of the Sarbanes Oxley Act of 2002, 13 REV. ACCT. STUD. (Mar. 2004), (October 2005), available at http://ssrn.com/abstract=830848, p. 29.

15. Hartman, Thomas, (2007) "the cost of being public in the era of Sarbanes-Oxley, Foley \& Larder, LLP, August 2.

16. Healey, Thomas \& Robert Steel, (2005). Sarbanes-Oxley Has Let Fresh Air Into Boardrooms, Financial Times, July 29, at 17.

17. Hsihui Chang et al., (2006) CEO's/CFO's Swearing by the Numbers: Does it Impact Share Price of the Firm?, 81 The Accounting Review. 1, 1.

18. Jain, P. K., and Z. Rezaee. (2006). The Sarbanes-Oxley Act of 2002 and security market behavior: Early evidence. Contemporary Accounting Research (Autumn): 23(3).

19. Koehn, J \& Del Vecchio, S. (2004). Ripple effects of the Sarbanes- Oxley Act, CPA Journal, 74(2), 36-40. Retrieved Friday, Nov 26, 2007 from the business Source Premier database.

20. Leuz, Christian, (2007). Was the Sarbanes-Oxley act of 2002 really costly? A Discussion of evidence from event returns and going-private decisions, Journal of Accounting and Economics, forthcoming.

21. Li, H., M. Pincus, and S. O. Rego. 2004. Market reaction to events surrounding the Sarbanes-Oxley Act of 2002. 2004 Annual Meeting of the American Accounting Association (AAA). Orlando, FL. August 8-11.

22. Pankaj K. Jain, Jang-Chul Kim, \& Zabihollah Rezaee, "The Effect of The Sarbanes-Oxley Act of 2002 on Market Liquidity" 29 (March 2004), available at http://ssrn.com/abstract=488142.

23. Pollock, Alex J. 2007, "Send Sarbanes-Oxley to the court of investors" The American, Available at: http://www.american.com/archive/2007/may-0507/send-sarbanes-oxley-to-the-court-of-investors

24. Prentice, Robert \& David Spence (2007), Sarbanes-Oxley as Quack Corporate Governance: How Wise is the Received Wisdom? Georgetown Law Journal, vol. 95, 1843-1944. 
25. PriceWaterhouseCoopers', "30\% of Fast-Growth Private Companies Applying Sarbanes-Oxley Principles," Trendsetter Barometer, June 21, 2005.

26. Sarbanes-Oxley Act of 2002. The Public Company Accounting Reform and Investor Protection Act. http://www.whitehouse.gov/infocus/corporateresponsibility. (H.R. 3763).

27. Shadab, Houman B., (2007), Innovation and corporate governance: the impact of Sarbanes-Oxley. Mercatus Center, George Mason University, Working Paper.

28. Sweeney, P. (2006), Sarbanes-Oxley report card is mixed. Financial Executive, 21(10), pp 22-25. Retrieved Friday, October 26, 2007 from the Business Source Premier database.

29. The ones that get away. (2005) Economist, retrieved Friday, October 26, 2007 from the Business Source Premier database.

30. Thomas E Hartman, "The cost of being public in the era of Sarbanes-Oxley," Foley \& Lardner, LLP, August 2, 2007

31. Zhang, Ivy Xiying, (2007). Economic consequences of the Sarbanes-Oxley Act of 2002, Working Paper, University of Minnesota. 


\section{NOTES}

